\title{
Circulating FSH isoform patterns during recurrent increases in FSH throughout the oestrous cycle of heifers
}

\author{
D. J. Cooke, M. A. Crowe* and J. F. Roche \\ Department of Animal Husbandry and Production, Faculty of Veterinary Medicine, University College \\ Dublin, Ballsbridge, Dublin 4, Ireland
}

\begin{abstract}
Blood samples were collected from heifers $(n=6 ; 450 \pm 7.7 \mathrm{~kg}) 2-4$ times a day during the first and second follicular waves, and during the gonadotrophin surge to determine whether changes in circulating FSH isoforms occur during cyclic quantitative changes in FSH throughout the oestrous cycle. Serum was assayed for FSH, LH, oestradiol and progesterone. Selected samples collected during the first (samples 1-3) and second (samples 4-6) postovulatory recurrent FSH increase and during the subsequent gonadotrophin surge (samples 7 and 8) were analysed for FSH isoforms by chromatofocusing. No change $(P>0.05)$ in isoform profile occurred during the first or second recurrent FSH increase, when oestradiol concentrations were $0.6 \pm 0.07$ and $0.6 \pm 0.09 \mathrm{pg} \mathrm{ml}^{-1}$ and progesterone concentrations were $0.03 \pm 0.01$ and $2.4 \pm 0.19 \mathrm{ng} \mathrm{ml}^{-1}$, respectively. The percentage of FSH eluting in the $\mathrm{pH}$ range $7.4-7.0$ increased $(P<0.05)$ from $14.2 \pm 2.2$ during the luteal phase (samples 1-6) to $20.2 \pm 2.3$ (sample 7) and $31.4 \pm 3.4 \%$ (sample 8) during the preovulatory gonadotrophin surge, while oestradiol concentrations were higher $(P<0.05$; $4.9 \pm 0.39 \mathrm{pg} \mathrm{ml}^{-1}$ ) than in the luteal phase of the cycle. In summary, FSH isoform patterns did not change during the cyclic quantitative changes in FSH associated with emergence of the first or second follicular wave. However, during the gonadotrophin surge, in association with increased oestradiol concentrations, an increase in the amount of less acidic isoforms of FSH was observed. Therefore, qualitative changes in FSH are not important in the physiological regulation of follicle turnover during the luteal phase of the oestrous cycle of heifers.
\end{abstract}

\section{Introduction}

Recurrent cyclic changes in concentrations of FSH during the oestrous cycle are associated with sequential follicular wave emergence in cattle (Adams et al., 1992; Sunderland et al., 1994). FSH exists as a series of isoforms which have been identified in urine, serum and pituitary extracts of several mammals (Harlin et al., 1986; Padmanabhan et al., 1992; Kojima et al., 1995). It is now accepted that the observed molecular heterogeneity of these hormones arises through differential post-translational modification of core carbohydrate structures, leading to hormones with identical amino acid sequences but with distinct carbohydrate moieties (Chappel, 1995; UlloaAguirre et al., 1995; Cooke et al., 1996). These carbohydrates differ in their relative amounts of terminal sialic acid or sulfate, yielding isoforms with different pI values; that is, those containing more sialic acid are described as being more acidic than those with less terminal sialylation. The overall biological activity of an isoform is influenced by the identity of its carbohydrate moieties, as illustrated by the fact that glycosylation has been shown to affect receptor binding ability, half-life

${ }^{*}$ Correspondence and reprint requests.

Received 12 February 1997. in vivo and the ability of a hormone to elicit second-messenger responses in target tissues (Morell et al., 1971; Liu et al., 1984; Calvo et al., 1986). There is substantial evidence for a role of the gonadal steroids, especially oestradiol, in modulating FSH heterogeneity. A change in FSH isoform profile has been observed during the oestrous cycle in hamsters (Cameron and Chappel, 1985) and rats (Ulloa-Aguirre et al., 1988) and during the human menstrual cycle (Padmanabhan et al., 1988). In these species, a shift from the more acidic (displaying less in vitro bioactivity) to the less acidic (displaying more in vitro bioactivity) isoforms of FSH has been observed during the follicular phase of the cycle when preovulatory concentrations of oestradiol are present.

To date, few studies have been carried out to characterize the patterns of circulating gonadotrophin isoforms in farm animals during different physiological states (Cooke et al., 1996). Many of the data generated are based on the patterns of isoforms present in the anterior pituitary rather than in the circulation (Chappel and Ramaley, 1985; Ulloa-Aguirre et al., 1988; Stumpf et al., 1992). However, analysis of circulating isoforms of $\mathrm{FSH}$, rather than those found in the pituitary (some of which may represent intermediates in the FSH biosynthetic pathway) will help determine if they play a biological role in relation to FSH action on follicular growth and development. 
Thus, the aim of this study was to characterize the pattern of circulating FSH isoforms at strategic stages of the oestrous cycle in heifers related to recurrent quantitative changes in FSH and follicular wave development. The specific hypothesis was that a shift in FSH isoforms from the more acidic to the less acidic forms would occur during the follicular phase (in the presence of high concentrations of oestradiol) compared with other stages of the cycle. In addition, it was hypothesized that no change in isoform profile would occur between the early luteal phase, when progesterone concentrations are low $\left(<1.0 \mathrm{ng} \mathrm{ml}^{-1}\right)$, and the luteal phase of the cycle, when progesterone concentrations are higher $\left(>2 \mathrm{ng} \mathrm{ml}^{-1}\right)$.

\section{Materials and Methods}

\section{Animals}

Eight crossbred beef heifers ( $450 \pm 7.7 \mathrm{~kg}$ body weight) were administered a prostaglandin $\mathrm{F}_{2 \alpha}$ analogue $\left(\mathrm{PGF}_{2 \alpha ;} ; 15 \mathrm{mg}\right.$ luprostiol; Prosolvin: Intervet Ireland Ltd, Finglas, Dublin) during the luteal phase to initiate luteolysis. Heifers were observed for oestrous behaviour four times a day for 3 days from $12 \mathrm{~h}$ after $\mathrm{PGF}_{2 u}$ injection. They were housed in slatted accommodation, had access to grass silage and water ad libitum, and were supplemented with $1.4 \mathrm{~kg}$ concentrate feed per heifer per day throughout the experimental period. Subsequently, $\mathrm{PGF}_{2 a}$ was injected on the second day of dominance of the second dominant follicle to induce luteolysis and ovulation of the second dominant follicle in all heifers. A follicle was defined as dominant when (i) it was $\geq 8.5 \mathrm{~mm}$ in diameter, (ii) it was $\geq 2 \mathrm{~mm}$ greater in diameter than any of the subordinate follicles in its cohort, and (iii) the subordinate follicles had become static or regressed based on daily ultrasound scanning of the ovaries (Mihm et al., 1994). All animal experimentation was performed in compliance with regulations set down by the BioMedical Centre, University College Dublin, and the Cruelty to Animals Act (Ireland), 1897.

\section{Scanning of ovaries and collection of blood samples}

From 2 days after the onset of oestrus, ovaries of heifers were scanned daily using an ultrasound scanner (Concept 500, Dynamic Imaging, Livingston) and a $7.5 \mathrm{MHz}$ transrectal linear probe. The size, number and location of all follicles $\geq 5 \mathrm{~mm}$ were recorded as described by Savio et al. (1988). From the onset of heat (day 0), $60 \mathrm{ml}$ blood samples were collected every $6 \mathrm{~h}$ for $48 \mathrm{~h}$; sampling frequency was then reduced to twice a day until day 4 and once a day on day 5 and day 6 . Twice a day, samples were collected from day 7 until $24 \mathrm{~h}$ after the second prostaglandin injection; thereafter, samples were collected every $6 \mathrm{~h}$ until the second dominant follicle ovulated. Blood samples were maintained at room temperature for $\mathrm{I} h$, at $4^{\circ} \mathrm{C}$ for $18-24 \mathrm{~h}$ and centrifuged at $1600 \mathrm{~g}$ for $20 \mathrm{~min}$. Serum was separated and divided into two aliquants of approximately $20 \mathrm{ml}$ and $5 \mathrm{ml}$. All serum samples were stored at $-20^{\circ} \mathrm{C}$ until assay. Serum samples were assayed for $\mathrm{FSH}, \mathrm{LH}$, oestradiol and progesterone (using the $5 \mathrm{ml}$ aliquant), while the larger samples were used for chromatofocusing of FSH isoforms.

\section{Hormone assays}

Previously validated radioimmunoassys were used to quantify oestradiol (Prendiville et al., 1995), progesterone (Ronayne and Hynes, 1990) and FSH (using USDA bFSH BI as the standard preparation; Crowe et al., 1997). Mean interassay coefficients of variation $(\mathrm{CV} ; n=3)$ for serum samples containing $1.4,2.9$ and $6.2 \mathrm{pg}$ oestradiol ml ${ }^{-1}$ were $17.2,14.3$ and $14.7 \%$, respectively, while the intra-assay CV $(n=6)$ for the same samples were $11.3,5.5$ and $7.1 \%$. The sensitivity of the oestradiol assay was $0.2 \mathrm{pg} \mathrm{ml}^{-1}$. In the progesterone assay, the mean interassay $\mathrm{CV}(n=4)$ for serum samples containing $0.2,0.8$ and $2.7 \mathrm{ng}$ progesterone $\mathrm{ml}^{-1}$ were $10.9,7.0$ and $6.4 \%$, respectively, while mean intra-assay $\mathrm{CV}(n=6)$ for the same samples were 9.1, 7.1 and $4.3 \%$. The sensitivity of the progesterone assay was $0.1 \mathrm{ng} \mathrm{ml}^{-1}$. The mean interassay CV $(n=4)$ for serum samples containing 10.7, 18.0 and 34.1 ng FSH ml ${ }^{-1}$ were $16.7,15.4$ and $6.4 \%$, respectively, while intra-assay $\mathrm{CV}(n=6)$ for the same samples were 10.5, 8.9 and $9.6 \%$. The assay sensitivity was $2.0 \mathrm{ng}$ USDA bFSH B1 ml ${ }^{-1}$. Fractions from chromatofocusing columns were assayed for FSH using a modified version of the assay described by Crowe et al. (in press). The sample volume was increased from $200 \mu \mathrm{l}$ to $400 \mu \mathrm{l}$ for both sample and standard. Assays were carried out at $4^{\circ} \mathrm{C}$ and standard curves were prepared using $0.025 \mathrm{~mol}$ imidazole $\mathrm{l}^{-1} \mathrm{HCl}, \mathrm{pH} 7.4$ as buffer. This increased the sensitivity of the assay from $2 \mathrm{ng}$ USDA bFSH B1 ml ${ }^{-1}$ to $0.5 \mathrm{ng}$ $\mathrm{ml}^{-1}$. Interassay $\mathrm{CV}(n=4)$ for serum samples containing 7.8, 16.6 and $22.2 \mathrm{ng}$ USDA bFSH BI ml ${ }^{-1}$ were 9.5, 10.5 and $14.1 \%$, respectively. Intra-assay $\mathrm{CV}(n=6)$ for the same samples were $11.9,10.0$ and $12.5 \%$.

Serum LH concentrations were determined by radioimmunoassay using a modification of the method described by Matteri et al. (1987). Briefly, $200 \mu \mathrm{l}$ aliquots of serum or standard (NIH bLH B9, NIDDK, MD), $100 \mu$ l of monoclonal antibody (518B7 anti LH-B; 1:150 000 dilution; supplied by J. Roser, University of California, Davis, CA) and $100 \mu \mathrm{l}$ bLH (USDA bLH-I-1 AFP-6000, $I^{125}$ ) radioligand (approximately 10000 c.p.m. per tube; iodinated using a mild chloramine- $\mathrm{T}$ procedure; Crowe et al., 1997) were added to $11 \mathrm{~mm} \times 64 \mathrm{~mm}$ polystyrene tubes on day 1 . Tubes were vortex-mixed and incubated at room temperature for $24 \mathrm{~h}$. On day 2, $50 \mu \mathrm{l}$ donkey anti-mouse second antibody (SAC-CELL, A-SAC 4, IDS, Boldon, Tyne and Wear) was added to each tube, vortexed and incubated at room temperature for $30 \mathrm{~min}, 250 \mu \mathrm{l}$ of distilled water was added and tubes were centrifuged for $5 \mathrm{~min}$ at $1600 \mathrm{~g}$. The supernatant was aspirated and amount of radioactivity of iodinated LH in the precipitate was determined using a gamma counter. Crossreactivity at $50 \%$ binding with bFSH (USDA bFSH I2) was $1.05 \%$. Mean interassay CV $(n=2)$ for samples containing 4.9 and $9.9 \mathrm{ng} \mathrm{LH} \mathrm{ml}^{-1}$ were 1.9 and $4.3 \%$, respectively. Intraassay CV $(n=6)$ for the same samples were 8.9 and $4.1 \%$, respectively. The sensitivity of the $\mathrm{LH}$ assay was $0.1 \mathrm{ng} \mathrm{ml}^{-1}$.

\section{Chromatofocusing of serum samples}

Serum samples were selected for chromatofocusing analysis so that FSH isoform profiles could be determined during the quantitative changes in FSH that occur throughout the cycle. Eight samples were analysed from each animal: samples $1-3$ 


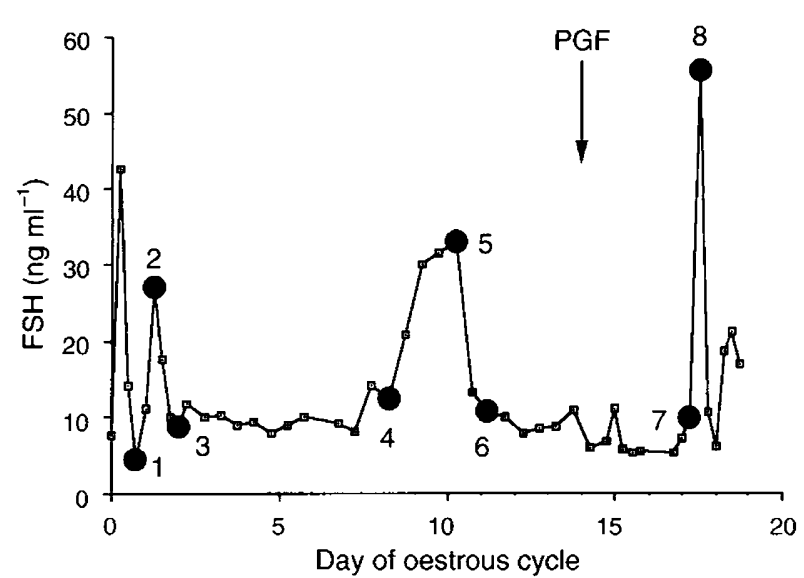

Fig. 1. FSH profile during the oestrous cycle (day $0=$ onset of oestrus) of a representative heifer administered prostaglandin $F_{2 a}$ (PGF) on the second day of dominance of the second dominant follicle leading to ovulation of this follicle. Samples analysed for FSH isoforms from the first and second recurrent FSH increase and from the gonadotrophin surge are indicated $(\mathbf{O})$.

correspond to the first FSH increase, samples 4-6 to the second FSH increase, while samples 7 and 8 were collected during the gonadotrophin surge (Fig. 1). Chromatofocusing was carried out as described by Padmanabhan et al. (1988). Briefly, $16 \mathrm{ml}$ serum samples were dialysed (molecular mass cut-off of dialysis tubing, $12000-14000 \mathrm{kDa}$ ) against $5 \mathrm{I}$ of $0.025 \mathrm{~mol}$ imidazole $\mathrm{I}^{-1} \mathrm{HCl}, \mathrm{pH} 7.4$, overnight, at $4^{\circ} \mathrm{C}$. Samples of dialysed serum (16 ml) were applied to chromatofocusing columns (bed height, $20 \mathrm{~cm}$; internal diameter, $1.0 \mathrm{~cm}$; PBE 94: Pharmacia, Uppsala) previously equilibrated in $0.025 \mathrm{~mol}$ imidazole $1^{-1} \mathrm{HCl}$, $\mathrm{pH}$ 7.4, eluted with a 1:10 dilution of Polybuffer 74 (Pharmacia, Uppsala) $\mathrm{HCl}, \mathrm{pH} 3.6$ at a flow-rate of $30 \mathrm{ml} \mathrm{h}^{-1}$, and approximately 95 fractions of $2 \mathrm{ml}$ were collected, while at $4^{\circ} \mathrm{C}$. This generated an elution gradient between $\mathrm{pH} 7.4$ and $\mathrm{pH}$ 3.6. Once the eluent decreased to $\leqslant \mathrm{pH} 3.8$, the elution buffer was changed to $I \mathrm{~mol} \mathrm{NaCl} \mathrm{I}^{-1}$ and a further $10-15$ fractions were collected. The $\mathrm{pH}$ of all fractions was measured and fractions were assayed for immunoreactive FSH the next day. After measurement of immunoreactive FSH in each eluent fraction, the amounts of FSH eluting in each of the $\mathrm{pH}$ ranges 7.4-7.0, 6.9-6.0, 5.9-5.0, 4.9-3.8 and in the salt peak were calculated as percentages of the total FSH recovered from the column.

\section{Statistical analyses}

One heifer developed cystic follicles during the induced oestrous cycle and another that failed to ovulate the second dominant follicle were excluded from the analyses. Changes in concentrations of $\mathrm{FSH}$, oestradiol and progesterone were evaluated by comparing mean hormone concentrations at different time points using paired $t$ test analysis. Mean LH concentrations were calculated and used to confirm the timing of the gonadotrophin surges, but did not undergo statistical evaluation. Changes in size of dominant follicles were evaluated by ANOVA of follicle diameter on different days of the cycle. The mean percentage of $\mathrm{FSH}$ eluting in each $\mathrm{pH}$ range of
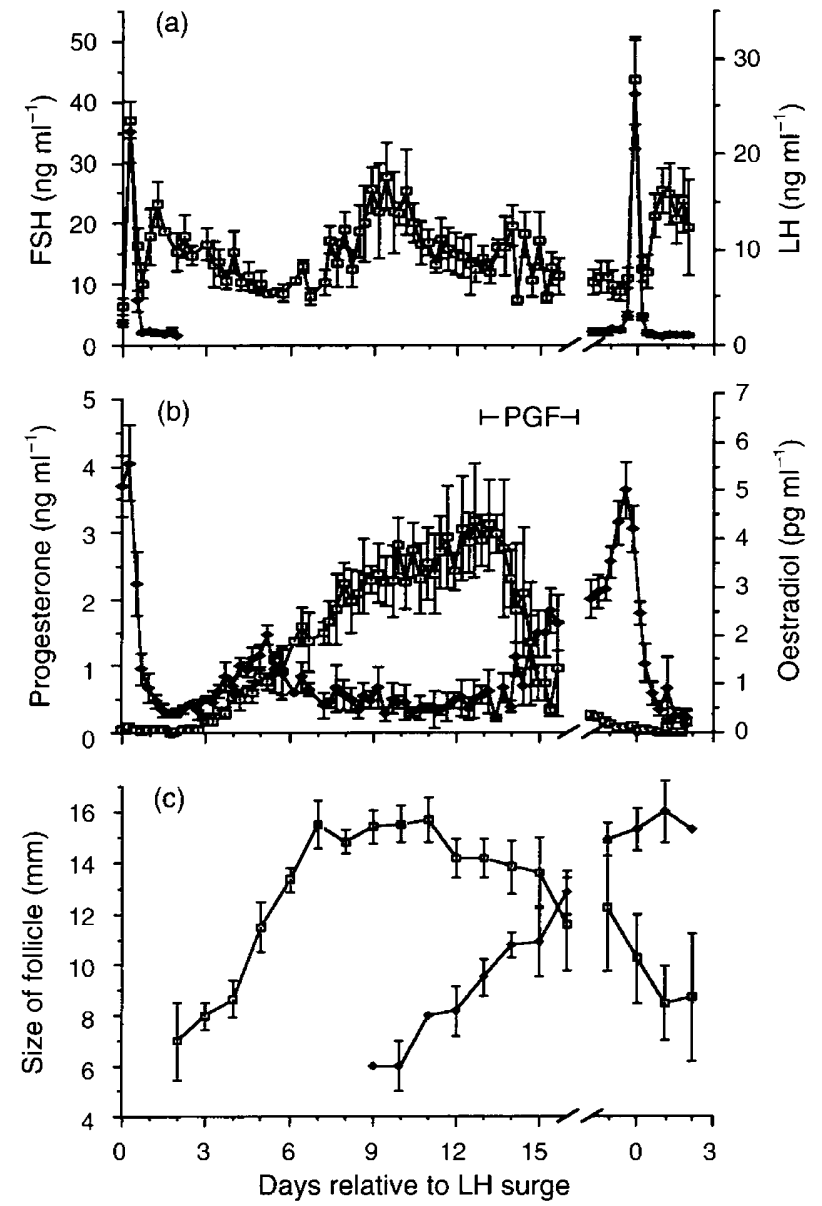

Fig. 2. (a) Gonadotrophin (FSH: $\square$; LH: $\bullet$ ) and (b) steroid hormone (progesterone: $\square$; oestradiol: $\bullet$ ) profiles (mean \pm sem; $n=6$ ) throughout the oestrous cycle of heifers. Data are aligned relative to the first LH surge (days 0-16; until the break in the $x$ axis) and then to the second LH surge (after the break in the $x$ axis). Prostaglandin $F_{2 u}$ (PGF) was administered on the second day of dominance of the second dominant follicle, initiating luteolysis and ovulation of the second wave dominant follicle in all heifers (dominance is defined as the first day a follicle from the second cohort was $\geq 2 \mathrm{~mm}$ in diameter than other cohort follicles and when cohort follicles remained static or decreased in size). (c) The pattern of follicle growth for the first (回) and second ( $\$$; in this case ovulatory) dominant follicles.

samples 1-8 from all heifers was calculated, and compared among samples using a general linear model ANOVA. Fisher's LSD test was used to determine specific differences between means after a significant $F$ test (Snedecor and Cochran, 1989).

\section{Results}

The first increase in FSH concentrations after the LH/FSH preovulatory surge occurred between day 0.5 and day 1.2 (day $0=$ oestrus) when concentrations (mean \pm SEM) increased $(P=0.002)$ from $9.8 \pm 1.2 \mathrm{ng} \mathrm{FSH} \mathrm{ml}^{-1}$ (day $0.5 \pm 0.1$ ) to a maximum of $24.1 \pm 3.3 \mathrm{ng} \mathrm{FSH} \mathrm{ml}^{-1}$ (day $1.2 \pm 0.1$; Fig. 2), and then decreased $(P<0.001)$ to $11.9 \pm 1.2 \mathrm{ng} \mathrm{FSH} \mathrm{ml}{ }^{-1}$. This increase in FSH concentration was coincident with decreasing concentrations of oestradiol and basal concentrations 
Table 1. FSH, oestradiol and progesterone concentrations (mean \pm SEM) in serum samples collected during the first and second recurrent FSH increase and during the gonadotrophin surge of the oestrous cycle of cattle, which were subsequently analysed for FSH isoforms

\begin{tabular}{|c|c|c|c|c|}
\hline $\begin{array}{l}\text { Sample } \\
\text { number }\end{array}$ & $\begin{array}{l}\text { Stage of } \\
\text { cycle }\end{array}$ & $\begin{array}{c}\text { FSH } \\
\left(\mathrm{ng} \mathrm{ml}^{-1}\right)\end{array}$ & $\begin{array}{l}\text { Oestradiol } \\
\left(\mathrm{pg} \mathrm{ml}^{-1}\right)\end{array}$ & $\begin{array}{l}\text { Progesterone } \\
\quad\left(\mathrm{ng} \mathrm{ml}^{-1} \text { ) }\right.\end{array}$ \\
\hline 1 & First FSH rise & $9.8 \pm 1.2^{\mathrm{a}}$ & $1.05 \pm 0.23^{\mathrm{d}}$ & $0.05 \pm 0.03^{\mathrm{d}}$ \\
\hline 2 & First FSH rise & $24.1 \pm 3.3^{\mathrm{b}}$ & $0.54 \pm 0.12^{\text {de }}$ & $0.02 \pm 0.01^{\mathrm{d}}$ \\
\hline 3 & First FSH rise & $12.0 \pm 1.2^{\mathrm{a}}$ & $0.39 \pm 0.05^{\mathrm{e}}$ & $0.01 \pm 0.01^{d}$ \\
\hline Mean 1-3 & First FSH rise & & $0.6 \pm 0.07^{x}$ & $0.03 \pm 0.01^{x}$ \\
\hline 4 & Second FSH rise & $14.7 \pm 1.5^{\mathrm{a}}$ & $0.68 \pm 0.15^{\mathrm{d}}$ & $2.03 \pm 0.31^{d}$ \\
\hline 5 & Second FSH rise & $28.8 \pm 2.7^{\mathrm{b}}$ & $0.67 \pm 0.18^{\mathrm{d}}$ & $2.42 \pm 0.38^{\mathrm{d}}$ \\
\hline 6 & Second FSH rise & $13.7 \pm 1.6^{\mathrm{a}}$ & $0.49 \pm 0.17^{\mathrm{d}}$ & $2.41 \pm 0.38^{d}$ \\
\hline Mean 4-6 & Second FSH rise & & $0.6 \pm 0.09^{x}$ & $2.29 \pm 0.19^{y}$ \\
\hline 7 & Gonadotrophin surge & $9.5 \pm 2.0^{a}$ & $5.01 \pm 0.58^{\mathrm{d}}$ & $0.06 \pm 0.03^{d}$ \\
\hline 8 & Gonadotrophin surge & $45.0 \pm 5.2^{\mathrm{c}}$ & $4.77 \pm 0.57^{\mathrm{d}}$ & $0.08 \pm 0.02^{\mathrm{d}}$ \\
\hline Mean 7-8 & Gonadotrophin surge & & $4.9 \pm 0.39^{y}$ & $0.06 \pm 0.01^{x}$ \\
\hline
\end{tabular}

\footnotetext{
a.b.c Within a column, means with different superscripts are different $(P<0.05)$.

${ }^{d, e}$ Within a stage of cycle, means with different superscripts are different $(P<0.05)$.

${ }^{x}$.yetween stages of cycle, means with different superscripts are different $(P<0.05)$.
}

of progesterone. Between day 2 and day 5, after the emergence of the first folliclular wave and in the presence of a growing dominant follicle, oestradiol concentrations increased $(P<0.001)$ from nadir values (mean \pm SEM) of $0.33 \pm 0.07 \mathrm{pg}$ oestradiol $\mathrm{ml}^{-1}$ to a maximum of $1.83 \pm 0.41 \mathrm{pg}$ oestradiol $\mathrm{ml}^{-1}$, and declined $(P=0.001)$ again to nadir concentrations by day 6 . Between day 3 and day 7 , the first dominant follicle increased in diameter (mean $\pm \mathrm{SEM} ; P<0.001$ ) from $8.0 \pm 0.5 \mathrm{~mm}$ to $15.5 \pm 1.0 \mathrm{~mm}$ and remained at this diameter $(P>0.2)$ until day 16 , when it decreased $(P<0.05)$ to $11.6 \pm 1.8 \mathrm{~mm}$. The second dominant follicle became dominant on day $13.5 \pm 0.4$ at a diameter of $10.6 \pm 0.3 \mathrm{~mm}$ and ovulated in all animals. A sustained basal increase $(P<0.001)$ in progesterone concentrations was observed between day 2.6 and day 14.0 (mean days), and then returned to basal concentrations by day 15 , in response to $\mathrm{PGF}_{2 \alpha}$ injection.

During the first FSH increase, oestradiol concentrations were higher $(P=0.01)$ in sample 1 compared with sample 3 ; however, there was no difference $(P>0.05)$ in oestradiol concentration between sample 2 and sample 3 (Table 1 ). Progesterone concentrations were not different $(P>0.05)$ in samples during the first FSH increase. Concentrations of oestradiol and progesterone did not differ $(P \geq 0.05)$ in samples collected during the second FSH increase (samples 4 to 6; Table I) or the preovulatory LH/FSH surge (samples 7 and 8; Table 1). However, oestradiol concentrations during the preovulatory LH/FSH surge (samples 7 and 8 ; Table 1 ) were higher $(P<0.001)$ than during the rest of the cycle (samples 1-6; Table 1); and progesterone concentrations in samples collected during the second FSH increase (samples 4-6; Table 1) were greater $(P<0.001)$ than in those collected during the first FSH increase or during the LH/FSH surge.

The chromatofocusing profiles of samples 1 and 8 from a representative heifer are shown (Fig. 3). There was no difference $(P \geq 0.7)$ in the FSH isoform profile in heifers during the first or second recurrent FSH increase (Table 2), despite the differences in circulating steroid concentrations. However, the FSH isoform profile was different in samples collected during the preovulatory rise, where a greater proportion of FSH eluted in the less acidic region of the $\mathrm{pH}$ gradient in sample 8 compared with samples 1-7. In samples 1-7, approximately $50 \%$ of $\mathrm{FSH}$ eluted in the salt peak, indicating that up to $50 \%$ of FSH in circulation at these times has a pl value less than 3.8 ( $\mathrm{pH} 3.8$ is the lower limit of the gradient). The percentage of FSH eluting in this region for sample 8 was decreased $(P<0.001)$ more than twofold. Between $10 \%$ and $20 \%$ of $\mathrm{FSH}$ eluted in the upper limit of the $\mathrm{pH}$ gradient in samples $1-7$, indicating the presence of FSH isoforms with a $\mathrm{pI}$ value $\geq 7.4$. An increase $(P<0.05)$ in the percentage of $\mathrm{FSH}$ eluting in the $\mathrm{pH}$ region 7.4-7.0 was observed in samples from the gonadotrophin surge (approximately 30\% for sample 8), compared with samples during the first and second recurrent FSH increase (1-6). The percentage of FSH eluting in this less acidic region (pH 7.4-7.0) in sample 7 was higher $(P<0.05)$ than in samples 2 and 4 . In addition, in sample 8, the percentage of FSH eluting in the $\mathrm{pH}$ region $6.9-6.0$ increased fourfold $(P<0.001)$, while the proportion of FSH eluting in the salt peak decreased twofold $(P<0.001)$ compared with samples 1-7.

\section{Discussion}

Despite distinct alterations in circulating $\mathrm{FSH}$ isoforms in a variety of species, at different physiological and developmental stages, the biological significance of FSH heterogeneity remains undetermined. Many of the studies carried out to date have examined FSH isoform distribution in the pituitary, owing to the relative abundance of FSH there. Fewer experiments have examined FSH forms in the circulation (Blum and Gupta, 1985; Padmanabhan et al., 1988, 1992; Shand et al., 1991; Hassing Downloaded from Bioscientifica.com at 04/26/2023 11:21:52AM 

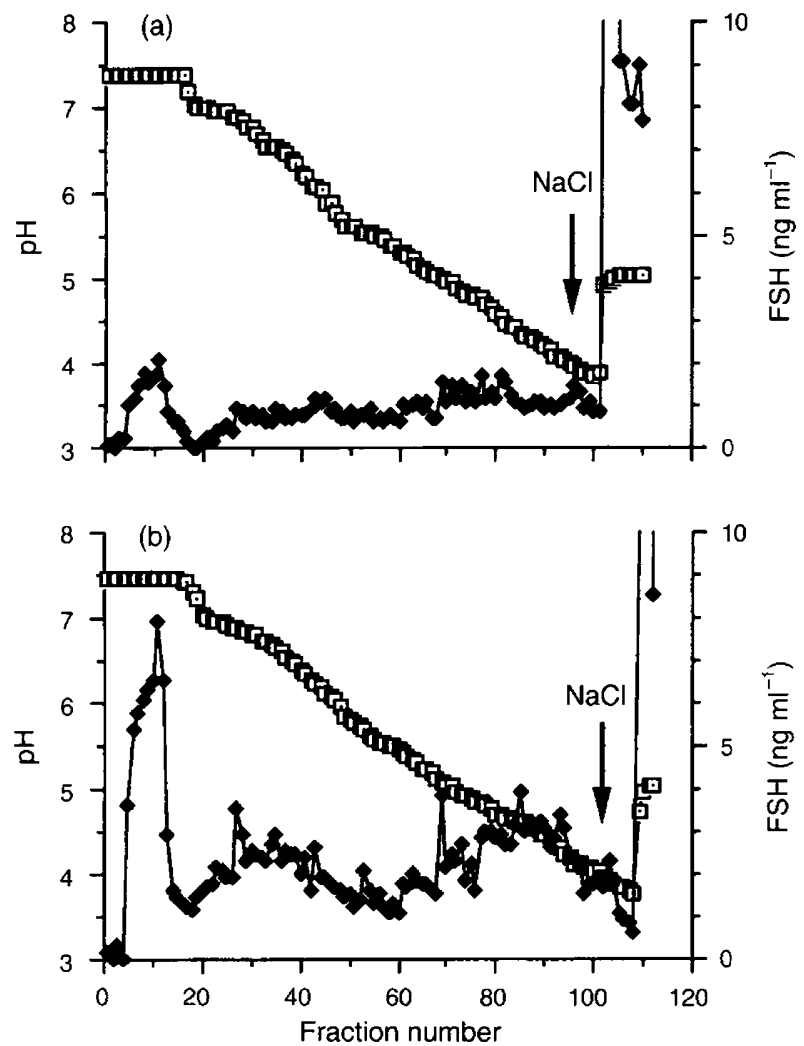

Fig. 3. Chromatofocusing profiles of FSH ( $)$ in two serum samples from a representative heifer. Sample 1 (a) was collected during the first recurrent FSH increase, while sample 8 (b) was collected during the gonadotrophin surge, of the oestrous cycle. Samples were loaded onto chromatofocusing columns and eluted with a $\mathrm{pH}$ gradient, as illustrated by the decreasing $\mathrm{pH}$ profile ( $\nabla$ ). Once the lower end of the $\mathrm{pH}$ gradient was reached, $1 \mathrm{~mol} \mathrm{NaCl} \mathrm{I}^{-1}$ was added (arrow) to elute any FSH remaining on the column. All fractions were assayed for FSH by radioimmunoassay.

et al., 1993; Wide and Bakos, 1993; Wide and Naessen, 1994) of species such as rats, humans, horses and sheep, and this is the first published study to do so in cattle.

This experiment shows that, during the oestrous cycle of cattle, the profile of circulating FSH isoforms is not different during luteal phase FSH increases but is different during the gonadotrophin surge of the follicular phase compared with the luteal phase. Specifically, an increase in the proportion of more basic isoforms $(\mathrm{pI} \geq 6.0$ ) was observed in serum at a time coincident with increased concentrations of oestradiol. This finding is in broad agreement with many of the studies of FSH heterogeneity in other species. Ulloa-Aguirre et al. (1988) reported that during the late morning and early evening of pro-oestrus in rats, associated with increased circulating concentrations of oestradiol and GnRH secretion, an increase in the percentage of less acidic $\mathrm{FSH}$ with a pI of 6.2-5.5 was observed. Cameron and Chappel (1985) examined FSH heterogeneity during the oestrous cycle and after ovariectomy in female golden hamsters, and found that the predominant forms $(86 \%)$ of FSH within and secreted in vitro from the anterior pituitary after ovariectomy (hence, in the absence of gonadal steroids) had pI values < 4.5. However, during dioestrus II, when oestradiol concentrations are high (Chappel et al., 1978), a large proportion of FSH ( $52 \%$ ) in the pituitary had more basic pl values (pI 7.5-4.5). During the oestrous cycle of ewes, Phillips et al. (1994) demonstrated that changes in circulating bioactive FSH (determined using a rat Sertoli cell bioassay) occur several times during the cycle; the bioactive:immunoactive (B:I) ratio of FSH increased in the late follicular phase, suggesting a greater proportion of more bioactive (basic) isoforms associated with increased oestradiol concentrations.

There are conflicting data in studies carried out during the human menstrual cycle. Padmanabhan et al. (1987) showed an increase in B:I ratio of FSH at the time of the gonadotrophin surge, while Jia et al. (1986) and Reddi et al. (1990) observed no change in B:I ratio during the different phases of the menstrual cycle. The discrepancy in these results may be explained by methodological differences, specifically, the use of different radioimmunoassays and in vitro bioassays. However, significant changes in B:I ratio within any one study suggest changes in the distribution of FSH isoforms.

It is unclear whether the shift in FSH isoforms observed in the present study was mediated directly through modulation of FSH secretion at the pituitary by oestradiol or through an oestradiol-mediated alteration in GnRH secretion. Several studies have reported an oestradiol-induced change in isoform profile in favour of more basic forms of the hormone in women (Padmanabhan 1988; Wide and Naessen, 1994) and men (Matikainen et al., 1994). However, direct administration of oestradiol to ovariectomized heifers (Kojima et al., 1995) failed to alter pituitary FSH isoforms compared with ovariectomized and cyclic control animals. In the present study, no change in FSH isoforms was observed during the first recurrent FSH increase, despite significant changes in oestradiol concentrations in the samples from this phase of the cycle. These results indicate that, in cattle, oestradiol alone does not appear to alter pituitary FSH isoform distribution. Stumpf et al. (1992) failed to show an alteration in pituitary FSH isoforms in heifers throughout sexual maturation, a time of presumed increase in GnRH secretion, in contrast to studies in other species (Chappel et al., 1983; Wide 1989). Many studies using GnRH antagonists (Kessel et al., 1988; Mortola et al., 1989; Matikainen et al., 1992), GnRH agonist (Kessel et al., 1988) and direct GnRH administration (Wide and Albertsson-Wikland, 1990; Phillips and Wide 1994) support a role for GnRH in control of FSH heterogeneity.

The lack of change in serum FSH isoforms during sequential FSH increases associated with different stages of the first and second waves of follicle growth during the oestrous cycle of heifers suggests that heterogeneity in bovine FSH is not biologically significant in the regulation of follicular wave dynamics. Although there is evidence of differential biological to immunological potency and circulatory clearance rates of FSH isoforms, the current data show that changes in isoform pattern in blood do not play a meaningful physiological role in relation to the FSH-induced emergence of a new follicular wave; neither do changes in this pattern seem to be critical in relation to the selection or subsequent atresia of the dominant follicle. Despite the differential functional capacities of different FSH isoforms demonstrated in vitro, the current data in heifers in vivo do support the contention that there is a putative change in FSH function during the preovulatory period, as well as the mainly circumstantial evidence that different FSH Downloaded from Bioscientifica.com at 04/26/2023 11:21:52AM 
Table 2. Pattern of FSH isoforms in serum samples taken during the first and second recurrent FSH increase and during the gonadotrophin surge of the bovine oestrous cycle

\begin{tabular}{|c|c|c|c|c|c|c|}
\hline \multirow{2}{*}{$\begin{array}{l}\text { Sample } \\
\text { number }\end{array}$} & \multirow[b]{2}{*}{ Stage of cycle } & \multicolumn{5}{|c|}{ Percentage of total FSH eluting per $\mathrm{pH}$ range (mean \pm sEM) } \\
\hline & & $\mathrm{pH} 7.4-7.0$ & $\mathrm{pH} 6.9-6.0$ & $\mathrm{pH} 5.9-5.0$ & $\mathrm{pH} 4.9-3.8$ & Salt peak \\
\hline 1 & First FSH rise & $14.2 \pm 2.0^{\mathrm{ab}}$ & $6.2 \pm 1.2^{\mathrm{a}}$ & $10.5 \pm 1.6$ & $19.7 \pm 1.7$ & $49.4 \pm 4.3^{\mathrm{ab}}$ \\
\hline 2 & First FSH rise & $13.2 \pm 2.1^{\mathrm{a}}$ & $5.2 \pm 1.6^{\mathrm{a}}$ & $7.6 \pm 1.8$ & $24.2 \pm 1.9$ & $49.8 \pm 3.2^{\mathrm{ab}}$ \\
\hline 3 & First FSH rise & $15.4 \pm 2.7^{\mathrm{ab}}$ & $5.6 \pm 1.1^{\mathrm{a}}$ & $9.9 \pm 1.5$ & $17.8 \pm 1.8$ & $51.3 \pm 3.0^{\mathrm{ab}}$ \\
\hline 6 & Second FSH rise & $14.2 \pm 2.2^{\mathrm{ab}}$ & $3.7 \pm 0.7^{\mathrm{a}}$ & $6.0 \pm 0.7$ & $18.4 \pm 2.4$ & $57.6 \pm 2.5^{\mathrm{a}}$ \\
\hline 7 & Gonadotrophin surge & $20.2 \pm 2.3^{b}$ & $4.4 \pm 0.5^{\mathrm{a}}$ & $8.6 \pm 0.7$ & $20.7 \pm 4.4$ & $46.0 \pm 4.2^{\mathrm{b}}$ \\
\hline 8 & Gonadotrophin surge & $31.4 \pm 3.4^{\mathrm{c}}$ & $15.3 \pm 1.4^{\mathrm{b}}$ & $10.6 \pm 0.7$ & $19.5 \pm 2.0$ & $23.1 \pm 1.3^{c}$ \\
\hline
\end{tabular}

a.b.c Means within a column with differing superscripts are different $(P<0.05)$

isoforms may play a role during the dynamic periovulatory period. These results highlight the fact that future research into FSH heterogeneity should focus on the demonstration of altered function of different FSH isoforms in vivo.

During the first and second recurrent increases in serum FSH concentrations of the oestrous cycle of heifers, the pattern of circulating FSH isoforms did not change. However, before and during the gonadotrophin surge, an increase in the percentage of less acidic isoforms in circulation was observed. In conclusion: (i) changes in concentration of progesterone are not involved in the regulation of FSH isoforms in cattle; (ii) oestradiol alone does not appear to be involved in the regulation of $\mathrm{FSH}$ heterogeneity; however, it may be involved in conjunction with other gonadal or hypothalamic factors (for example, GnRH) in regulating circulating isoforms of $\mathrm{FSH}$; and (iii) FSH pleiomorphism is not important in the physiological regulation of follicle turnover throughout the cycle, but may play an as yet undetermined role in the events around the time of ovulation.

The authors are grateful to M. Mihm and P. Duffy for ultrasound scanning of heifers and assistance with collection of blood samples; to N. Hynes, G. Claffey, S. McDonnell and S. Ni Cheallaigh for assistance with radioimmunoassays, to D. R. Headon (University College Galway) for initial assistance with chromatofocusing and to T. Harte and the staff at Lyons Research farm for the maintenance and care of experimental animals. The authors acknowledge Clonatec Ltd, (Paris) for providing antiserum (Pi 531B) for the progesterone radioimmunoassay, J. Roser (Department of Animal Science, University of California, Davis, CA) for providing LH antiserum, the NHPP of the $\mathrm{NIH}$ for provision of FSH antiserum (AFP-C5288113) and FSH for iodination (AFP-4177A) and D. Bolt (USDA, Beltsville, MD) for providing bovine FSH standard. This research was supported by EU AAIR grant number $92 / 1124$ and a Forbairt basic research award $\mathrm{BR} / 93 / 162$.

\section{References}

Adams GP, Matteri RL, Kastelic JP, Ko JCH and Ginther OJ (1992) Association between surges of follicle-stimulating hormone and the emergence of follicular waves in heifers Journal of Reproduction and Fertilify 94 177-188
Blum WFP and Gupta D (1985) Heterogeneity of rat FSH by chromatofocusing: studies on serum FSH, hormone released in vitro and metabolic clearance rates of its various forms Journal of Endocrinology 105 29-37

Calvo FO, Keutmann HT, Bergert ER and Ryan RS (1986) Deglycosylated human follitropin: characterisation and identification of effects on adenosine cyclic $3^{\prime}, 5^{\prime}$-phosphate production in porcine granulosa cells Biochemistry 25 $3938-3943$

Cameron JL and Chappel SC (1985) Follicle-stimulating hormone within and secreted from anterior pituitaries of female golden hamsters during the estrous cycle and after ovariectomy Biology of Reproduction 33 132-139

Chappel SC (1995) Heterogeneity of follicle-stimulating hormone: control and physiological function Human Reproduction Update 1 (5) 479-487

Chappel SC and Ramaley JA (1985) Changes in the isoelectric focusing profile of pituitary follicle-stimulating hormone in the developing male rat Biology of Reproduction 32 567-573

Chappel SC, Norman RL, and Spies HG (1978) Effects of oestradiol on serum and pituitary gonadotropin concentrations during selective elevations of folliclestimulating hormone Biology of Reproduction 19 159-166

Chappel SC, Ulloa-Aguirre A and Ramaley J (1983) Sexual maturation in female rats: time related changes in the isoelectric focusing pattem of anterior pituitary follicle-stimulating hormone Biology of Reproduction 28 196-205

Cooke DJ, Crowe MA, Roche JF and Headon DR (1996) Gonadotrophin heterogeneity and its role in farm animal reproduction Animal Reproduction Science 41 77-99

Crowe MA, Padmanabhan V, Hynes N, Sunderland SJ, Enright WJ, Beitins IZ and Roche JF Validation of a sensitive radioimmunoassay to measure serum follicle-stimulating hormone in cattle: correlation with FSH bioassay Animal Reproduction Science $\mathbf{4} 7$ in press

Harlin J, Khan SA and Diczfalusy E (1986) Molecular composition of luteinizing hormone and follicle-stimulating hormone in commercial gonadotrophin preparations Fertility and Sterility 46 1055-1061

Hassing JM, Kletter GB, l'Anson H, Woods RI, Beitins IZ, Foster DL and Padmanabhan V (1993) Pulsatile administration of gonadotrophin-releasing hormone does not alter the follicle-stimulating hormone (FSH) isoform distribution pattem of pituitary or circulating FSH in nutritionally growth restricted ovariectomized lambs Endocrinology 132 1527-1536

Jia XC, KesseI B, Yen SSC, Tucker EM, Hseuh AJW (1986) Serum bioactive follicle-stimulating hormone during the menstrual cycle and in hyper- and hypogonadotropic states: application of a sensitive granulosa cell aromatase bioassay Journal of Clinical Endocrinology and Metabolism 62 1243-1248

Kessel B, Dahl KD, Kazer RR, Liu CH, Rivier J, Vale W, Hseuh AJW and Yen SSC (1988) The dependancy of bioactive follicle-stimulating hormone secretion on gonadotropin-releasing hormone in hypogonadal and cycling women Journal of Clinical Endocrinology and Metabolism 66 361-366

Kojima FN, Cupp AS, Stumpf TT, Zalesky DD, Roberson MS, Werth LA, Wolfe MW, Kittok RJ, Grotjan HE and Kinder JE (1995) Effects of $17 \beta$ estradiol on distribution of pituitary isoforms of luteinizing hormone and follicle-stimulating hormone during the follicular phase of the bovine estrous cycle Biology of Reproduction 52 297-304 
Liu WK, Young JD and Ward DN (1984) Deglycosylated ovine lutropin: preparation and characterization by in vitro binding and steroidogenesis Molecular and Cellular Endocrinology 37 29-39

Matikainen T, Ding Y-Q, Vergona M, Huhtaniemi I, Couzinet B and Schaison G (1992) Differing responses of plasma bioactive and immunoreactive FSH and $\mathrm{LH}$ to $\mathrm{GnRH}$ antagonist and agonist treatments in postmenopausal women Journal of Clinical Endocrinology and Metabolism 75 820-825

Matikainen T, Haavisto AM, Permi J, deKnetser D and Huhtaniemi I (1994) Effects of oestrogen treatment on serum gonadotrophin bioactivity, immunoreactivity and isohormone distribution, and on immunoreactive inhibin levels, in prostatic cancer patients Clinical Endocrinology 40 743-750

Matteri RL, Roser JF, Baldwin DM, Lipovetsky V and Papkoff H (1987) Characterization of a monoclonal antibody which detects luteinizing hormone from diverse mammalian species Domestic Animal Endocrinology 4(3) 157-165

Mihm M, Baguisi A, Boland MP and Roche JF (1994) Association between the duration of dominance of the ovulatory follicle and pregnancy rate in beef heifers Journal of Reproduction and Fertility 102 123-130

Morell AG, Gregoriadis G, Scheinberg IH, Hickman J and Ashwell G (1971) The role of sialic acid in determining the survival of glycoproteins in circulation journal of Biological Chemistry 246 1461-1467

Mortola JF, Sathanandan M, Pavlou S, Dahl KD, Hsueh AJW, Rivier J, Vale W and Yen SCC (1989) Suppression of bioactive and immunoreactive folliclestimulating hormone and luteinizing hormone levels by a potent gonadotropin-releasing hormone antagonist: pharmacodynamic studies Fertility and Sterility 51 957-963

Padmanabhan V, Chappel SC and Beitins IZ (1987) An improved in vitro bioassay for follicle-stimulating hormone (FSH): suitable for measurement of FSH in unextracted human serum Endocrinology 121 1089-1098

Padmanabhan V, Lang LL, Sonstein J, Kelch RP and Beitins IZ (1988) Modulation of serum follicle-stimulating hormone bioactivity and isoform distribution by estrogenic steroids in normal women and in gonadal dysgenesis Journal of Clinical Endocrinology and Metabolism 67 465-473

Padmanabhan V, Mieher CD, Borondy M, l'Anson H, Wood RI, Landefeld TD, Foster DL and Beitins I (1992) Circulating bioactive follicle-stimulating hormone and less acidic follicle-stimulating hormone isoforms increase during experimental induction of puberty in the female lamb Endocrinology $131213-220$

Phillips DJ and Wide L (1994) Serum gonadotropin isoforms become more basic after an exogenous challenge of gonadotropin-releasing hormone in children undergoing pubertal development Joumal of Clinical Endocrinology and Metabolism 79 814-819

Phillips DJ, Hudson HL, Gentle LR and McNatty KP (1994) Bioactive folliclestimulating hormone concentrations in plasma during the estrous cycle of the ewe Biology of Reproduction 51 1292-1298

Prendiville DJ, Enright WJ, Crowe MA, Finnerty M, Hynes N and Roche JF (1995) Immunization of heifers against gonadotropin-releasing hormone: antibody titres, ovarian function, body growth and carcass characteristics journal of Animal Science 73 2382-2389

Reddi K, Wickings EJ, McNeilly AS, Baird DT and Hillier SG (1990) Circulating bioactive follicle-stimulating hormone and immunoreactive inhibin levels during the normal human menstrual cycle Clinical Endocrinology 33 547-557

Ronayne E and Hynes N (1990) Measurement of plasma progesterone concentrations by extraction and non-extraction radioimmunoassys Irish Journal of Agricultural Research 29 109-115

Savio JD, Keenan L, Boland MP and Roche JF (1988) Pattern of growth of dominant follicles during the oestrous cycle of heifers Journal of Reproduction and Fertility 83 663-671

Shand N, Alexander SL and Irvine CHG (1991) Comparison of the microheterogeneity of horse LH and FSH in the pituitary with that secreted into pituitary venous blood at oestrus Journal of Reproduction and Fertility Supplement 44 1-11

Snedecor GW and Cochran WG (1989) Statistical Methods 8th edn. lowa State University Press, Ames

Stumpf TT, Roberson MS, Wolfe MW, Zalesky DD, Cupp AS, Werth LA, Kojima N, Hejl K, Kittok RJ, Grotjan HE and Kinder JE (1992) A similar distribution of gonadotropin isohormones is maintained in the pituitary throughout sexual maturation in the heifer Biology of Reproduction 46 442-450

Sunderland SJ, Crowe MA, Boland MP, Roche JF and Ireland JJ (1994) Selection, dominance and atresia of follicles during the oestrous cycle of heifers Journal of Reproduction and Fertility $101547-555$

Ulloa Aguirre A, Esponoza R, Damian-Matsumura P, Larrea F, Flores A, Morales L and Dominguez $\mathbf{R}$ (1988) Studies on the microheterogeneity of anterior pituitary follicle-stimulating hormone in the female rat. Isoelectric pattern throughout the estrous cycle Biology of Reproduction 38 70-78

Ulloa-Aguirre A, Midgley AR Jr, Beitins IZ and Padmanabhan V (1995) Folliclestimulating isohormones: characterization and physiological relevance Endocrine Reviews 16 (6) 765-787

Wide L (1989) Follicle-stimulating hormones in anterior pituitary glands from children and adults differ in relation to sex and age Journal of Endocrinology 123 519-529

Wide A and Albertsson-Wikland K (1990) Change in electrophoretic mobility of human follicle-stimulating hormone in serum after administration of gonadotropin-releasing hormone Journal of Clinical Endocrinology and Metabolism 70 271-276

Wide L and Bakos O (1993) More basic forms of both human folliclestimulating hormone and luteinizing hormone in serum at mid-cycle compared with the follicular and luteal phase Journal of Clinical Endocrinology and Metabolism 76 885-889

Wide L and Naessen T (1994) $17 \beta$-estradiol counteracts the formation of the more acidic isoforms of follicle-stimulating hormone and luteinizing hormone after menopause Clinical Endocrinology (Oxford) 40 78-789 